\section{Anticyclic Citrullinated Peptide Antibodies as Markers of Erosive Arthritis in Antisynthetase Syndrome}

\section{To the Editor:}

We read with interest the recent letter by Nagashima, et al ${ }^{1}$, who suggested that destructive/erosive arthropathy in anti-Jo-1-positive patients with dermatomyositis (DM) sine myositis is another disease subset, classifiable as DM sine myositis overlapping with rheumatoid arthritis (RA). Moreover, the authors state that anticyclic citrullinated peptide antibodies (anti-CCP) are useful for distinguishing subluxing from destructive arthropathy in this setting. We describe our experience on the topic.

We have followed 12 anti-Jo-1-positive patients ( 8 women, 4 men, ages 46-78 yrs) with antisynthetase syndrome (Table 1). The disease spectrum is characterized by the occurrence of cutaneous findings in all cases ("mechanic's hands"), interstitial lung involvement in all cases (by chest high resolution computed tomography, pulmonary function tests, and DLCO), myositis (8/12 patients; muscle biopsy), and arthritis (11/12 patients; clinical observation). All arthritis patients satisfied American College of Rheumatology classification criteria for RA (symmetrical arthritis of wrists and metacarpophalangeal and proximal interphalangeal joints, prolonged morning stiffness); the single patient without arthritis had inflammatory hand pain. Low titer IgM rheumatoid factor (RF; by immunonephelometry) was found in 3 patients (with 29,42 , and $78 \mathrm{IU} / \mathrm{ml}$, normal value $<20$ ), whereas anti-CCP antibodies (commercial second-generation ELISA kit) were present in 2 patients (with 14 and $162 \mathrm{IU} / \mathrm{ml}$, normal value $<6$ ), together with RF. Erosions were assessed by radiographs of hands and feet. Marginal erosions were found in 2 patients who were anti-CCP-positive. Joint erosions were statistically associated with anti-CCP $(p=0.045$, Fisher's exact test $)$ but not with RF-IgM $(p=0.127)$.

With regard to the cases described by Nagashima, et al, all our patients with erosive arthritis also had clinical and biopsy-proven inflammatory myositis; we also confirmed the association between erosivity and anti-CCP in anti-Jo-1-positive patients. To date there are several reports evaluating the meaning of anti-CCP antibodies in connective tissue diseases other than RA; in systemic sclerosis (SSc) ${ }^{2}$ and systemic lupus ery- thematosus (SLE) ${ }^{3}$ these antibodies are markers of erosive arthritis, as we suggest in antisynthetase syndrome. In contrast, in Sjögren's syndrome ${ }^{4}$ this association is lacking, although anti-CCP seem to be closely associated with the occurrence of synovitis.

Taking the literature data into account, we suggest that a RA-like arthritis may be present in patients who are anti-Jo-1-positive, independent of the occurrence of myositis. Moreover, the risk of erosive disease in this setting is closely related to anti-CCP positivity, similarly to SSc and SLE.

\section{LORENZO CAVAGNA, MD; CHIARA FUSETTI, MD;} CARLOMAURIZIO MONTECUCCO, MD; ROBERTO CAPORALI, MD, Division of Rheumatology, University of Pavia and IRCCS Foundation Policlinico S. Matteo, P. le Golgi 3, 27100 Pavia, Italy. Address correspondence to Dr. Cavagna; E-mail: lorenzo.cavagna@unipv.it

\section{REFERENCES}

1. Nagashima T, Sato H, Minota S. Destructive arthropathy associated with dermatomyositis sine myositis positive for anti-Jo-1 and anti-cyclic citrullinated peptide antibodies [letter]. J Rheumatol 2009;36:2133-4.

2. Ingegnoli F, Galbiati V, Zeni S, Meani L, Zahalkova L, Lubatti C, et al. Use of antibodies recognizing cyclic citrullinated peptide in the differential diagnosis of joint involvement in systemic sclerosis. Clin Rheumatol 2007;26:510-4.

3. Chan MT, Owen P, Dunphy J, Cox B, Carmichael C, Korendowych $\mathrm{E}$, et al. Associations of erosive arthritis with anti-cyclic citrullinated peptide antibodies and MHC class II alleles in systemic lupus erythematosus. J Rheumatol 2008;35:77-83

4. Atzeni F, Sarzi-Puttini P, Lama N, Bonacci E, Bobbio-Pallavicini F, Montecucco C, et al. Anti-cyclic citrullinated peptide antibodies in primary Sjögren syndrome may be associated with non-erosive synovitis. Arthritis Res Ther 2008;10:R51.

J Rheumatol 2010;37:9; doi:10.3899/jrheum.091402

Table 1. Characteristics of anti-Jo-1-positive patients with antisynthetase syndrome.

\begin{tabular}{|c|c|c|c|c|c|c|c|c|c|}
\hline Patient & Sex/Age & Followup, yrs & ILD & Myositis & $\begin{array}{l}\text { RA-like } \\
\text { Arthritis }\end{array}$ & $\begin{array}{c}\text { Joint } \\
\text { Erosions }\end{array}$ & Anti-ENA & $\begin{array}{c}\text { Anti-CCP, } \\
\text { IU } / \mathrm{ml}\end{array}$ & $\mathrm{RF}, \mathrm{IU} / \mathrm{ml}$ \\
\hline 1 & M 78 & 4 & Yes & Yes & Yes & No & Jo-1/Ro & Neg & Neg \\
\hline 3 & F 74 & 3 & Yes & Yes & Yes & No & Jo-1 & $\mathrm{Neg}$ & $\mathrm{Neg}$ \\
\hline 4 & F 78 & 6 & Yes & No & Yes & No & Jo-1/Ro & $\mathrm{Neg}$ & 42 \\
\hline 5 & M 73 & 4 & Yes & No & Yes & No & Jo-1/Ro & $\mathrm{Neg}$ & Neg \\
\hline 8 & F 56 & 9 & Yes & Yes & Yes & No & Jo-1/Ro & $\mathrm{Neg}$ & Neg \\
\hline 9 & F 78 & 5 & Yes & Yes & Yes & No & Jo-1 & $\mathrm{Neg}$ & $\mathrm{Neg}$ \\
\hline 10 & F 63 & 11 & Yes & Yes & Yes & No & Jo-1/Ro & $\mathrm{Neg}$ & Neg \\
\hline 11 & F 57 & 10 & Yes & No & Yes & No & Jo-1 & $\mathrm{Neg}$ & $\mathrm{Neg}$ \\
\hline 12 & F 62 & 3 & Yes & Yes & Yes & Yes & Jo-1 & 162 & 78 \\
\hline
\end{tabular}

ILD: interstitial lung disease; RA: rheumatoid arthritis; ENA: extractable nuclear antigen antibodies; CCP: citric citrullinated peptide antibodies; RF: rheumatoid factor. 